\title{
Placement of Battery Energy Storage for Provision of Grid Services - A Bornholm Case Study.
}

Hameed, Zeenat; Hashemi Toghroljerdi, Seyedmostafa; Ipsen, Hans Henrik; Træholt, Chresten

Published in:

Proceedings of $9<$ sup $>$ th $</$ sup $>$ International conference in smart energy grid engineering

Link to article, DOI:

10.1109/SEGE52446.2021.9535006

Publication date:

2021

Document Version

Peer reviewed version

Link back to DTU Orbit

Citation (APA):

Hameed, Z., Hashemi Toghroljerdi, S., Ipsen, H. H., \& Træholt, C. (2021). Plaffement of Battery Energy Storage for Provision of Grid Services - A Bornholm Case Study. In Proceedings of $9^{\text {In }}$ International conference in smart energy grid engineering IEEE. https://doi.org/10.1109/SEGE52446.2021.9535006

\section{General rights}

Copyright and moral rights for the publications made accessible in the public portal are retained by the authors and/or other copyright owners and it is a condition of accessing publications that users recognise and abide by the legal requirements associated with these rights.

- Users may download and print one copy of any publication from the public portal for the purpose of private study or research.

- You may not further distribute the material or use it for any profit-making activity or commercial gain

- You may freely distribute the URL identifying the publication in the public portal 


\title{
Placement of Battery Energy Storage for Provision of Grid Services - A Bornholm Case Study
}

\author{
Zeenat Hameed ${ }^{1}$, Seyedmostafa Hashemi ${ }^{2}$, Hans Henrik Ipsen ${ }^{3}$, Chresten Træholt ${ }^{4}$ \\ Department of Electrical Engineering, Technical University of Denmark ${ }^{1,2,4}$ \\ Bornholm Energi and Forsyning, Rønne, Denmark ${ }^{3}$ \\ zeeha@elektro.dtu.dk ${ }^{1}$, shtog@elektro.dtu.dk ${ }^{2}$, hhi@beof.dk ${ }^{3}$, ctr@elektro.dtu.dk ${ }^{4}$
}

\begin{abstract}
Battery energy storage systems (BESSs) are gaining potential recognition in modern power systems. They enable higher renewable shares in power networks by overcoming issues introduced by the intermittent nature of renewable resources. BESSs also provide various grid services such as frequency regulation, voltage support, energy management, and black start. Choosing an appropriate BESS location plays a key role in maximizing benefits from its services. This paper aims at investigating BESS placement for providing grid services at the point of installation. The previous studies extended in this direction have not considered the requirements of a real project under which BESS is being deployed and have mainly proposed solutions for standard IEEE bus systems. Also, the focus has not been on providing ancillary services using BESS, but mainly on loss minimization. This paper, on the other hand, presents a case study on the BESS placement problem by investigating various potential locations in Bornholm Island for fulfilling the objectives of a BESS-related industrial project, namely BOSS. This is achieved by considering factors like stackability of BESS-services, integration of large-scale renewable resources, and viability of business models.
\end{abstract}

Keywords-battery energy storage systems, BESS placement, grid services, renewable integration, Bornholm power system, ancillary services

\section{INTRODUCTION}

Higher electricity demands and rising awareness on environmental issues has led to developments in power systems. Integration of renewables in the generation mix are gaining potential recognition. Energy storage systems (ESSs) are also becoming increasingly prominent in fulfilling longterm decarbonization strategies [1]. This is because, for largescale renewable energy sources (RES) integration, deploying an ESS is generally a practical solution to overcome the uncertainty and variability challenges [2]. Out of various ESS technologies available, lithium-ion BESSs have emerged to be a cost-effective option, owing to the price reduction they have experienced over the last few years along with the promising technical characteristics they possess [3].

BESSs can be used to provide grid services to various stakeholders in power systems such as transmission and distribution system operators, plant owners and consumers [4]. Moreover, BESSs do not require specific geographical features for their installation as opposed to other ESSs technologies such as pumped hydro. This gives them added placement flexibility, allows them to be deployed at various locations in the power system, and helps them in providing grid services close to their installation location. However, as BESS installation at a less appropriate location can have a negative impact on the value of its services, BESS placement

This work is supported by the Danish project "BOSS: Bornholm smartgrid secured by grid-connected battery systems" co-founded by Danish Energy Technology Development and Demonstration Program (EUDP) contract no. 64018-0618. studies are of paramount importance. In a BESS-based project, choosing appropriate BESS installation site requires several careful investigations. This includes considering the interests of various stakeholders involved in the project, fulfilling technical criteria set forth by different manufacturers and suppliers, meeting technical and regulatory requirements regarding BESS connection with the grid, respecting local plans, and assessing local plans and customer needs [5], [6].

From the review articles such as [7], [8], it can be seen that BESS placement studies have mainly considered a reduction system losses whereas placement decisions based on BESS-services and RES integration have rarely been targeted. Also, most BESS placement studies, such as [9]-[14] have used models with standard IEEE bus systems to demonstrate appropriate BESS locations. Such simulations targeting reduction in system losses fail to capture the goals of real BESS-based projects. As the site selection for utility-scale BESS is a holistic process and since no two projects are the same, the BESS placement process must consider the aims and objectives of the project at hand. So, studies targeting cases where proposed BESS has been integrated into the real power grid are important. Even though regulatory and technical requirements for BESS installation might differ from country to country, however, different BESS-based projects have certain goals in common. For example, the goal of a BESSbased project might be to achieve higher revenues, enhance customer satisfaction or increase renewable integration. Thus, the importance of investigating a case study for handling the BESS placement problem cannot be denied.

Therefore, this paper investigates a case study for BESS placement on the Danish island of Bornholm. Bornholm is chosen as a test site as it represents a scaled model of Danish power system with an ability to operate in both grid-connected and islanded mode of operation [15]. It has a high amount of installed RES with around 35MW of wind powered generation and 23MW of solar powered generation. The paper has five sections. Section II presents an overview of services a BESS can provide when installed at different grid levels. Section III details the goals and objectives of the BOSS project under which the case study is being conducted. Section IV investigates the case study for BESS-placement by discussing the benefits and drawbacks of BESS installation at various potential locations. The paper ends with a conclusion on an appropriate choice for BESS placement in section V.

\section{OVERVIEW OF BESS SERVICES IN POWER SYSTEMS}

A hierarchical structure exists in a conventional grid. Four different voltage levels exist, namely, extra-high voltage (XHV), high voltage (HV), medium voltage (MV), and low voltage (LV). Electricity is fed at $\mathrm{HV}$ level where voltage has to be kept higher to reduce the $\mathrm{I}^{2} \mathrm{R}$ losses. However, as higher voltage requires greater insulation which comes at a higher cost, therefore, closer to the point of consumption, electricity 
is supplied at a lower voltage level [16] [17]. BESSs can be deployed at any of these voltage levels in the power network and provide grid services. They can provide frequency and voltage support, increase RES self-consumption, defer network upgrade investments, etc. [18], [19]. A brief overview of some of these services is presented in this section.

\section{A. BESS Services for Control Reserves}

Power imbalance between production and consumption in a power system causes rise and fall in grid-frequency and creates a need for frequency regulation. In such a situation BESSs can be charged or discharged to keep the frequency within pre-set limits [20], [21]. Traditionally, to provide frequency regulation, synchronous generators have been used, where a part of their capacity equivalent to the capacity of the largest onsite generation was reserved for performing primary frequency regulation (PFR) [22]. Contrarily, when BESS is used for PFR, its size and location have to be interpreted based on the most severe contingency for generation outage [23].

\section{B. BESS Services for Energy Trade and Management}

Energy trade and management refer to the controlled flow and smart use of electricity for efficiently saving energy and money. It includes services like peak shaving and load levelling. BESS availability at a particular location allows excess energy to be stored for later use, which helps customers in avoiding high electricity bills. Moreover, as usually need for network upgrades arise during peak demand hours, BESS installation also helps in deferring investments in network upgrades by lowing system stress [2], [24].

\section{BESS Services for System Restart and RES Integration}

In an event of complete grid failure, large-scale BESSs can provide black start services. Even though black start requires high restoration power, however, as it is a rare event, the installed BESS capacity can be used to provide other services in addition to black start [25], [26].

BESS can be incorporated in the power network to achieve higher renewable integration. During periods of high RES availability, BESSs help in storing excess generation of RES plants, thereby, preventing renewable energy curtailment [27], [28]. In such cases, it is essential to investigate the location for both RES plant and BESS for different network conditions. The location of BESS must be chosen based on the RES integration capacity.

\section{OVERVIEW OF THE BOSS PROJECT}

The case study in this paper is carried out under the BOSS project. BOSS stands for Bornholm Smartgrid Secured - by grid-connected battery systems. It aims at installing the largest grid-connected utility-scale BESS in Denmark with a battery capacity of $1 \mathrm{MW} / 1 \mathrm{MWh}$. The BESS is lithium-ion based and is to be installed on the Danish island of Bornholm.

The main focus of the BOSS project is to contribute to future green energy systems and aid developments in electrical energy storage. By integrating high RES penetration with high BESS capacity, the BOSS project will explore and demonstrate cost-effective, market-based BESS services and validate the stability and security of modern power systems [29]. The grid service related objectives of the BOSS project that are dependent on the choice of battery location are presented in Fig.1. as follows:

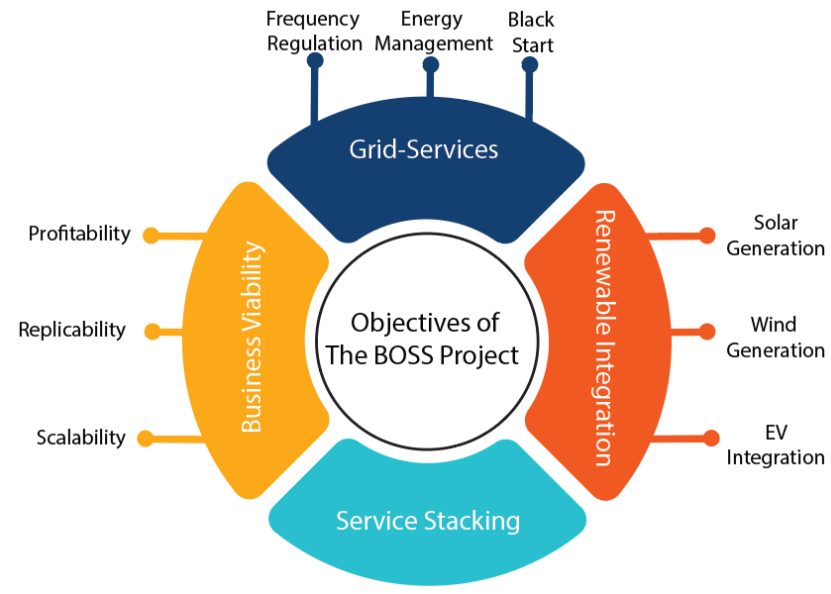

Fig. 1: The Grid Service-Related Objectives of the BOSS project

- Integration of renewable resources

- Stacking of grid services

- Viability of business models

Depending on the grid voltage level where BESS has been placed, different ancillary services can be targeted. The BOSS project is mainly focused on services such as frequency regulation, energy management, and black start. It aims to investigate these services for the Bornholm power system when it is working in grid-connected and islanded mode.

A high amount of RES availability at the point of BESS installation is also an important deciding factor for choosing a BESS location. There are many areas on Bornholm island with large scale renewable generation. Choosing an area with a variety of generation plants such as solar, wind, and biomass power plants is important for the BOSS project, as it would enable studying multiple use cases of BESS operation along with a diverse mix of available RES.

The need for stacking BESS services in the BOSS project derives from the fact that so far it is not cost-efficient to use storage devices for a single service owing to their high installation and maintenance costs [30]. But BESS installation cannot provide all the services at the same time, as a commitment to one or a few often means that the system is not available to provide other services. Therefore, the BESS location must be chosen in a way that the maximum number of services can be targeted.

Finally, as the BOSS project aims to deliver market-based BESS services, the choice of battery location must consider the viability of business cases at the point of installation. A BESS deployed at an inappropriate location can hinder the revenue generated from its services thus affecting the profitability of the BOSS project. The choice of BESS location should also serve as a viable testing site to replicate and up-scale the services applied in the BOSS project in the Danish commercial market.

- Provision of grid services 


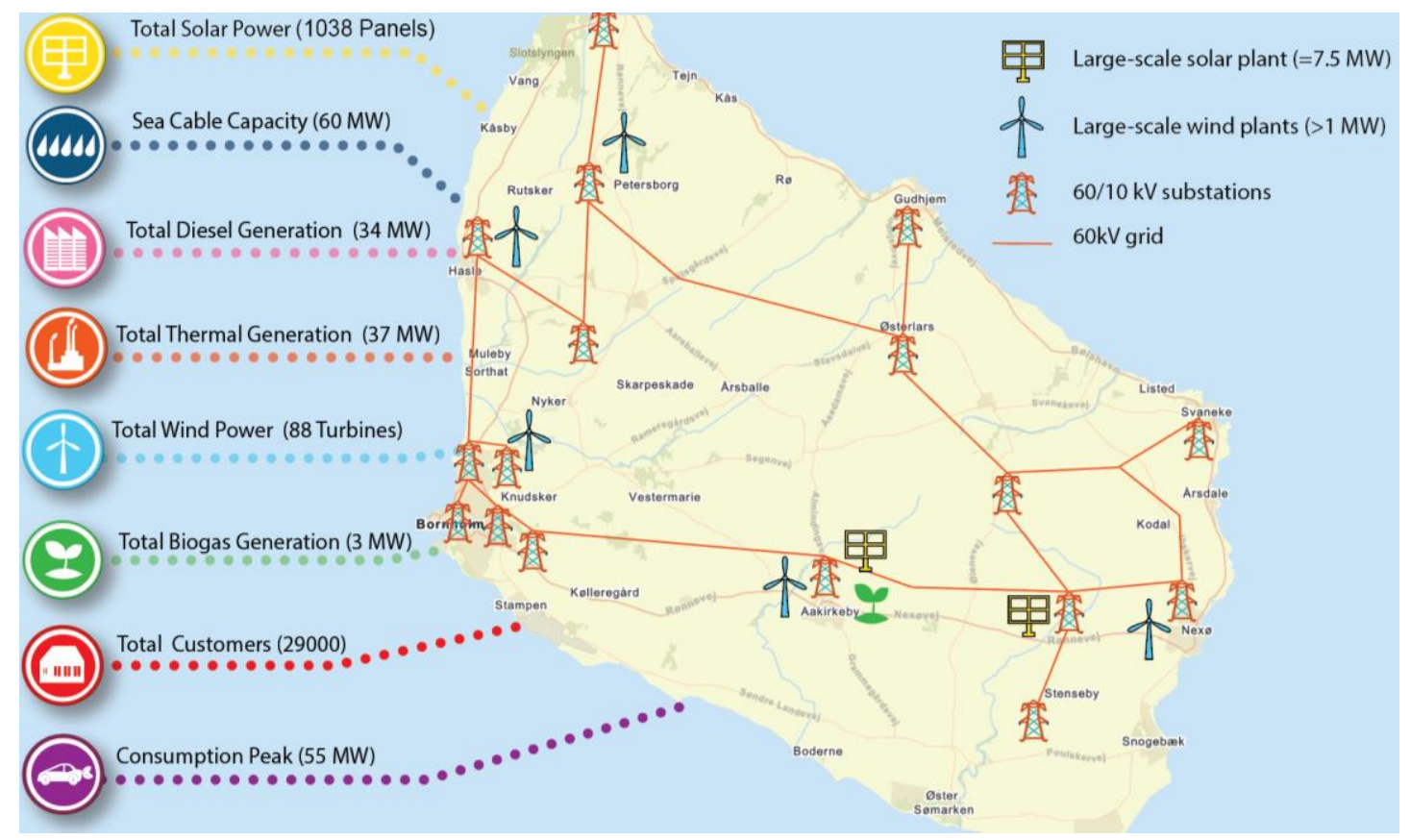

Fig. 2: Installed generation and consumption capacity at Bornholm power system

\section{CASE Study}

A description of Bornholm's network is presented in this section to understand its voltage and consumption levels, installed generation, and large-scale renewable installations.

\section{A. Description of the Bornholm Power System}

The power system of the Bornholm Island consists of four main networks, they are

- 132/60kV substation in Sweden

- $60 \mathrm{kV}$ network in Bornholm

- $10 \mathrm{kV}$ network

- $0.4 \mathrm{kV}$ network

E-ON is the power company operating in the southern Sweden. It owns the two transformers of $132 / 60 \mathrm{kV}$ rating connected to the Borrby substation. Bornholm Island's power system is connected to Sweden's power station through one of these transformers at the Hasle substation.

There are sixteen substations of $60 / 10 \mathrm{kV}$ in the Bornholm power network, as represented in Fig.2. [31]. The HV level of the network consists of a $60 \mathrm{kV}$ grid which is illustrated in orange lines in Fig.2. The MV grid-level is of $10 \mathrm{kV}$ which form the distivution system level of the Bornholm network, while the $\mathrm{LV}$ grid-level is of $0.4 \mathrm{kV}$.

Electricity is generated on the Bornholm Island through a number of renewable resources such as solar energy, wind energy, biomass energy, etc. Thus, making the island selfsufficient under normal circumstances. In Fig.2. the circles outside the Bornholm map, show the total generation capacity of installed solar plants, wind turbines, diesel generators, biomass plants, and thermal generators. Fig.2. illustrates two locations with large-scale PV plants installed. It also shows while large-scale wind farms at five locations. Out of 88 wind turbines installed, a total of 35MW wind power is produced from turbines the capacity of which is greater than $25 \mathrm{~kW}$, while $0.48 \mathrm{MW}$ is produced from the ones with a capacity of less than $25 \mathrm{~kW}$. Similarly, out of 1038 installed solar panels, $15 \mathrm{MW}$ of solar power is produced by large scale PV plants while $8 \mathrm{MW}$ is produced from residentially installed PVs.

The island produces $70 \%$ of its own renewable energy while importing the rest from Sweden using a 60MW sea cable through Hasle substation. It is represented in Fig.2. by a blue circle outside the map of Bornholm. When The sea cable is disconnected, the Bornholm Island operates in an islanded mode and relies on diesel generators for back up of energy supply [17]. 34MW of electrical power can be produced with the diesel generators.

Finally, Fig.2. also shows the a consumption peak of 55MW. This is based on 2019 data of 29000 connected customers. Keeping in view this generation and consumption mix of the Bornholm island and the BOSS objectives, an investigation on BESS placement location is conducted.

\section{B. Methodoloy}

The procedure to investigate BESS placement location is illustrated in Fig.3. First three-level criteria to assess each objective of the project is defined. Using this criteria, integration of RES is assigned a value of ' 0 ' at the installation locations where integration of neither solar nor wind plants is possible. It is assigned a value of ' 1 ' where integration of one of them is possible, and a value of ' 2 ' where integration of both is possible. Similarly, locations where no service stacking is possible, are assigned a value of ' 0 ,' while locations where at most two services can be stacked are assigned a value of ' 1 .' Moreover, a weight is also assigned to each objective. As providing grid services and integrating renewables hold significant importance for the BOSS project, these objectives are assigned a weight of 1 . On the other hand, service stacking and business viability are assigned 0.25 and 0.5 respectively. Fulfillment of each project objective at the prospective location is assessed on the three-level criteria, and the location with highest weighted sum of scores is chosen to be the BESS installation location. 


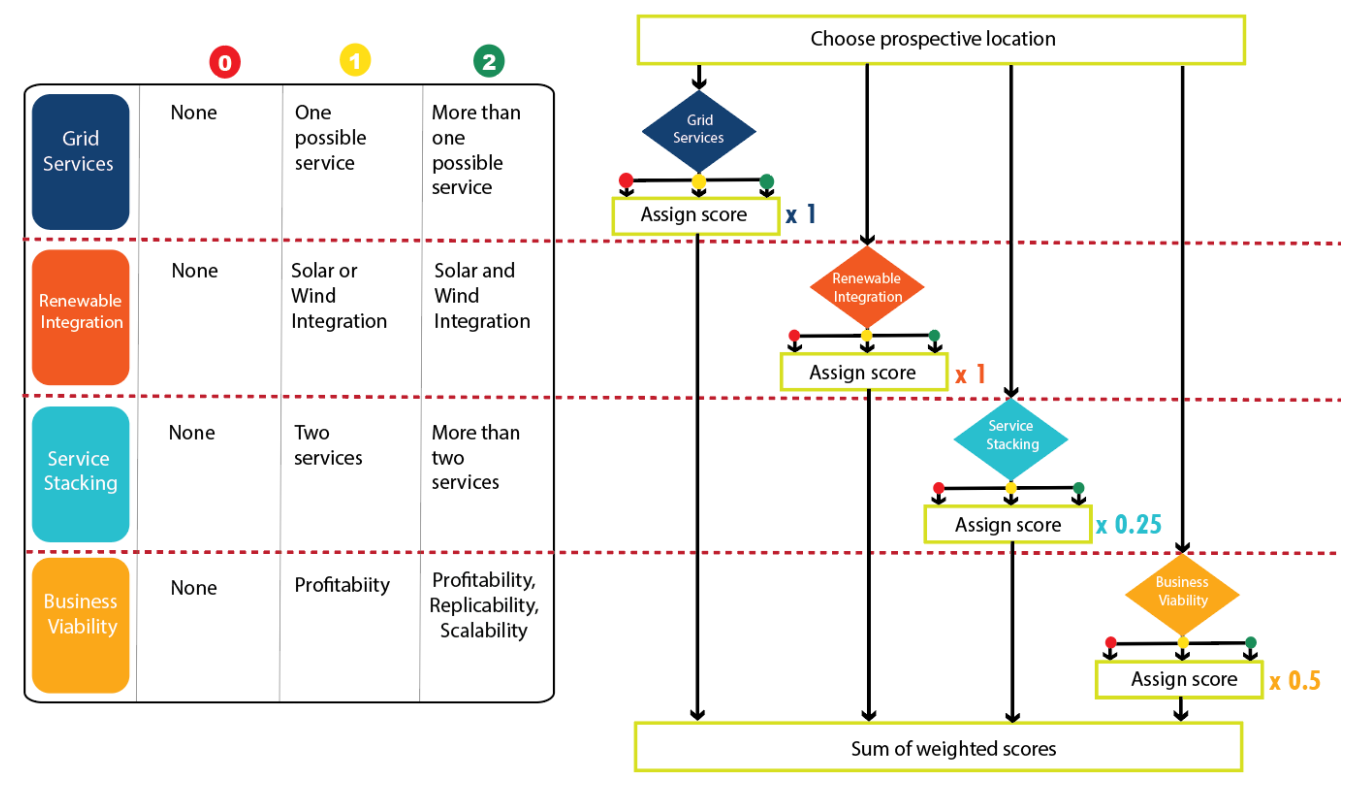

Fig. 3: Procedure for investigating BESS Placement in Bornholm Power System

\section{BESS Placement for Provision of Grid Services}

As far as the provision of frequency control reserves is concerned, the power supplied by BESSs influences the frequency in the same manner at all the voltage levels. However, since customers ate mainly connected at the LV or MV grid-levels, these voltage levels present more practical connection points[32]. Similarly, even though all grid levels present a possibility of energy trade and management through services such as peak shaving and load shifting, but LV and MV grid levels are the most suitable as based on the customer's behaviour, BESS utilization is maximized [32].

On the other hand, since HV grid-level has higher power requirements, it allows black start service to be better targeted. However, large BESS capacity is needed for this purpose. Due to the BOSS-BESS capacity of $1 \mathrm{MW}$, targeting black start in the HV grid-level is not a feasible option. For the same reasons, using BESS as an uninterruptable power supply (UPS) is also not applicable in HV level. In short, to fulfill the BOSS objective of providing services such as frequency regulation, energy management, and black start, the MV and LV grid levels are attractive locations.

\section{BESS Placement for Integration of Renewable Resources}

Due to higher renewable integration, power networks experience short peaks in LV and MV grid levels, thus giving rise to a need for grid support, which a BESS can fulfill especially well if situated in those grid levels [32]-[34].

For incorporating renewables within Bornholm's MV grid, there are multiple potential BESS locations available as there are sixteen substations currently present. But as the BOSS project has a strong focus on high RES synergies, therefore, substations with only residential RES generation are not preferred. Fig.2. illustrates Åkirkeby to be the only substation with large scale PV plants as well as wind generators installed. The wind plants connected at Bodilsker have recently been connected to Nexø. In contrast to Åkirkeby, other substations, present an option to study and monitor either large scale wind farms, as in the case of Hasle, or large scale solar plants as in the case of Bodilsker, but not both. Fig.4. illustrates the production profile at different substations in MV grid pf Bornholm.

RES integration can also be targeted at the LV grid where large scale residential PV installations are present. Moreover, as $\mathrm{LV}$ grid-level provides a potential to integrate electric vehicles (EVs), it can also be considered as a potential location for the BESS placement in the BOSS project. This can be achieved by considering a divided installation of BESS capacity, and placing the assembly with lower capacity in the LV grid. However, it is important to consider the maximum production and consumption at different transformer stations in the LV grid. Production and consumption profile at station 132, 650 and 690 are shown in Fig.4. As the consumption profile at station 650 is lower, deploying BESS at this station would underutilize its installed capacity. On the other hand, stations where consumption and production profiles are similar better BESS utilization can be targeted, for example, at station 132 .

\section{E. BESS Placement for Stacking of Grid Services}

There are many stakeholders involved in the BOSS project, including the energy supply companies such as Bornholm Energi and El-net Øst, private firms such as Nuvve, Danfoss, Lithium Balance, and European Energy, a testing facility such as PowerLabDK, as well as research facility such as and Technical University Denmark [35]-[40]. It also involves the customers connected to the Bornholm network.

Number of BESS services, and their associated value streams vary depending on the BESS installation location [30]. Therefore, while considering the stacking of services, the requirements of different stakeholders must essentially be considered. This is because some services appear to be more appealing to certain stakeholders. For example, stacking energy arbitrage with peak shaving is attractive for customers as it may help customers in reducing electricity bills. On the other hand, PFR due to its recognition of a high value service, is particularly important for the BOSS project for generating higher revenues. However, stacking of PFR conflicts with large number of services because of high power requirements. Finally, for research facilities involved in the project, using 
a) Possible BESS Installation Locations in Medium Voltage Grid of the Bornholm Power System

\begin{tabular}{|l|c|c|c|c|c|}
\hline $60 \mathrm{kV}$ st. & $\begin{array}{c}\text { PV } \\
{[\text { no } / \mathrm{MW}]}\end{array}$ & $\begin{array}{c}\text { PV Domestic } \\
{[\mathrm{no} / \mathrm{MW}]}\end{array}$ & $\begin{array}{c}\text { WTG } \\
{[\mathrm{no} / \mathrm{MW}]}\end{array}$ & $\begin{array}{c}\text { WTG } \\
\text { Domestic } \\
{[\mathrm{no} / \mathrm{MW}]}\end{array}$ & $\begin{array}{c}\text { Biogas } \\
{[\text { [no / }} \\
\text { MW] }\end{array}$ \\
\hline Bodilsker & $1 / 7.5$ & $69 / 0.34625$ & & $3 / 0.022$ & \\
\hline Hasle & & $77 / 0.6773$ & $10 / 16.08$ & $5 / 0.0246$ & \\
\hline Nexø & & $88 / 0.8564$ & $3 / 2.7$ & $2 / 0.055$ & \\
\hline Olsker & & $68 / 0.53685$ & $6 / 2.05$ & $3 / 0.022$ & \\
\hline Snorrebakken & & $60 / 0.63885$ & $5 / 2.66$ & $1 / 0.025$ & \\
\hline Ákirkeby & $1 / 7.5$ & $114 / 0.9925$ & $8 / 12.5$ & $11 / 0.117$ & $2 / 1.5$ \\
\hline
\end{tabular}

Possible BESS Installation Locations in Low Voltage Grid-Level of the Bornholm Power System (b, c, d)

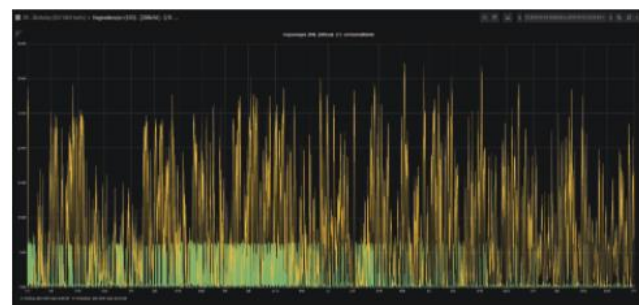

c) Station 650 Maximum Production $=32.16 \mathrm{~kW}$

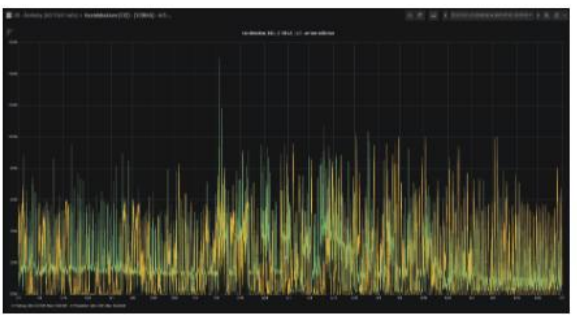

b) Station 132 Maximum Production $=10.2 \mathrm{~kW}$ Maximum Consumption $=15.0 \mathrm{~kW}$

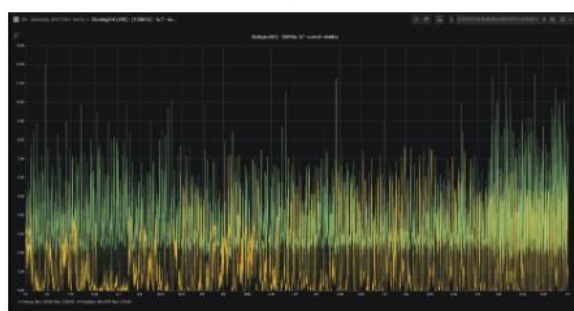

d) Station 690 Maximum Production $=7.9 \mathrm{~kW}$

Maximum Consumption $=12.08 \mathrm{~kW}$

Fig. 4: Renewable generation profile at different locations in MV and LV grid-levels of the Bornholm power system

BESS for novel and less tested services such as black start is important.

\section{F. BESS Placement for Viability of Business Models}

In a market setting, technical, regulatory, and economic parameters govern the potential of BESS applications, which is encapsulated by the BESS business models. These models help in monetizing the BESS value [41]-[43]. Increased access to and higher value from the BESS services improves the business potential of BESS projects [44]. Similarly, higher RES integration allows the BESS to avoid dependence on grid electricity, thus cutting projects' electricity costs. Moreover, allocating specific days of BESS operation to provide high revenue services such as PFR, while targeting other services for remaining days also helps in achieving a profitable business. For the BOSS project, both MV and LV grid levels hold the potential to integrate higher renewables and stacking various services, thus proving to be viable business locations for the BESS installation.

Applying the above discussion to the BESS placement procedure illustrated in Fig.3. the weighted sum of scores for Åkirkeby, Hasle, and station 132 are 5.5, 4.5, and 3.75 respectively. This is because Åkirkeby gets a score of 2 for all 4 objectives, while Hasle scores 1 for renewable integration as only wind plants are available at this substation. Similarly, stations at the LV grid score lower as they show less business viability owing to their limited BESS capacity utilization.

\section{CONCLUSIONS}

In this paper, we investigated the placement of a utilityscale BESS for providing grid services and conducted a case study on the Bornholm power system while considering the objectives of the BOSS project. The aim was to install a $1 \mathrm{MW} / 1 \mathrm{MWh}$ BESS providing grid services to the Bornholm power system, which is a power system with a high share of RES. We concluded that the BESS can be installed at both MV and LV grid levels to provide multiple grid services. However, the installation of BESS at an MV substation has less limitations with regards to the required permissions from authorities, and better BESS capacity utilization. We found that Akirkeby substation at the MV grid-level was the best location with availability of both large-scale PV plants and wind generators, which presents a suitable location for high scale RES integration, thus ensuring better service stackability and business viability. We also found that both MV and LV grid-level can be targeted for provision of majority of the BESS services in the Bornholm Island. We concluded that if an option of a divided installation in both MV and LV grids is considered, the higher capacity of BESS should be installed at the MV grid. We also concluded that to fulfill the diverse requirements of multiple stakeholders involved in the BOSS project, BESS services can be stacked in a variety of ways when it is placed in the MV grid of the Bornholm power system.

\section{REFERENCES}

[1] [1] IRENA, Global energy transformation: A roadmap to 2050 (2019 edition). 2019.

[2] [2] E. Storage, F. O. R. Future, and E. U. Role, "Energy storage for future energy systems and eu role and initiatives," vol. 2, no. 2, pp. 129, 2019.

[3] [3] T.-T. Nguyen, V. Martin, A. Malmquist, and C. A. S. Silva, "A review on technology maturity of small scale energy storage technologies," Renew. Energy Environ. Sustain., vol. 2, p. 36, 2017, doi: $10.1051 /$ rees/2017039.

[4] [4] "Business \& Technology Report Battery Energy Storage Overview," 2019.

[5] [5] V. Sultan, A. Alzahrani, H. Bitar, and B. Hilton, "A Conceptual Framework for Battery Storage Integration into the Electric Grid," Proc. - 2017 Int. Conf. Comput. Sci. Comput. Intell. CSCI 2017, pp. 161-167, 2018, doi: 10.1109/CSCI.2017.25.

[6] [6] S. Tripathy, Q. Deng, D. Tylavsky, T. Stowers, and R. Hess, "Establishing the Stacked Value of Battery Energy Storage in Electric Power Systems," 2018 North Am. Power Symp. NAPS 2018, 2019, doi: 10.1109/NAPS.2018.8600615.

[7] [7] M. Stecca, L. Ramirez Elizondo, T. Batista Soeiro, P. Bauer, and P. Palensky, "A Comprehensive Review of the Integration of Battery Energy Storage Systems into Distribution Networks," IEEE Open J. Ind. Electron. Soc., vol. 1, no. February, pp. 1-1, 2020, doi: 10.1109/ojies.2020.2981832. 
[8] [8] B. Yang et al., "Optimal sizing and placement of energy storage system in power grids: A state-of-the-art one-stop handbook," $J$ Energy Storage, vol. 32, no. May, p. 101814, 2020, doi: 10.1016/j.est.2020.101814.

[9] [9] S. B. Karanki, D. Xu, B. Venkatesh, and B. N. Singh, "Optimal location of battery energy storage systems in power distribution network for integrating renewable energy sources," 2013 IEEE Energy Convers. Congr. Expo. ECCE 2013, pp. 4553-4558, 2013, doi: 10.1109/ECCE.2013.6647310.

[10] [10] D. I. Karadimos, A. D. Karafoulidis, D. I. Doukas, P. A. Gkaidatzis, D. P. Labridis, and A. G. Marinopoulos, "Technoeconomic analysis for optimal energy storage systems placement considering stacked grid services," Int. Conf. Eur. Energy Mark. EEM, 2017, doi: 10.1109/EEM.2017.7981898.

[11] [11] F. García-Muñoz, F. Díaz-Gonzalez, C. Corchero, and C. NuñezDe-Toro, "Optimal Sizing and Location of Distributed Generation and Battery Energy Storage System," Proc. 2019 IEEE PES Innov. Smart Grid Technol. Eur. ISGT-Europe 2019, pp. 1-5, 2019, doi: 10.1109/ISGTEurope.2019.8905609.

[12] [12] A. Alzahrani, H. Alharthi, and M. Khalid, "Minimization of power losses through optimal battery placement in a distributed network with high penetration of photovoltaics," Energies, vol. 13, no. 1, 2019, doi: 10.3390/en13010140.

[13] [13] Y. Zhang, S. Ren, Z. Y. Dong, Y. Xu, K. Meng, and Y. Zheng, "Optimal placement of battery energy storage in distribution networks considering conservation voltage reduction and stochastic load composition," IET Gener. Transm. Distrib., vol. 11, no. 15, pp. 3862 3870, 2017, doi: 10.1049/iet-gtd.2017.0508

[14] [14] M. Farsadi, T. Sattarpour, and A. Y. Nejadi, "Optimal placement and operation of BESS in a distribution network considering the net present value of energy losses cost," ELECO 2015 - 9th Int. Conf. Electr. Electron. Eng., pp. 434-439, 2016, doi: 10.1109/ELECO.2015.7394582.

[15] [15] “BOSS.” https://boss-project.com/ (accessed Nov. 30, 2020).

[16] [16] "Delivery to consumers - U.S. Energy Information Administration https://www.eia.gov/energyexplained/electricity/delivery-to(EIA)." consumers.php (accessed Jul. 07, 2020).

[17] [17] C. Boss, B. Smartgrid, and K. Brunak, "Site Selection Criteria for Utility-Scale Battery Integration," 2019.

[18] [18] N. Sharma and S. Sankar, "Modeling and Control of Battery Energy Storage System for Providing Grid Support Services," Clemson Univ. Power Syst. Conf. PSC 2018, 2019, doi: 10.1109/PSC.2018.8664018.

[19] [19] L. Maeyaert, L. Vandevelde, and T. Döring, "Battery Storage for Ancillary Services in Smart Distribution Grids," J. Energy Storage, vol. 30, no. April, p. 101524, 2020, doi: 10.1016/j.est.2020.101524.

[20] [20] T. International Renewable Energy Agency, UTILITY-SCALE BATTERIES INNOVATION LANDSCAPE BRIEF. 2019.

[21] [21] I. S. Jha, S. Sen, M. Tiwari, and M. K. Singh, "Control strategy for Frequency Regulation using Battery Energy Storage with optimal utilization," in India International Conference on Power Electronics, IICPE, May 2015, vol. 2015-May, doi: 10.1109/IICPE.2014.7115796.

[22] [22] D. Mejía-Giraldo, G. Velásquez-Gomez, N. Muñoz-Galeano, J. B. Cano-Quintero, and S. Lemos-Cano, "A BESS sizing strategy for primary frequency regulation support of solar photovoltaic plants," Energies, vol. 12, no. 2, pp. 1-16, 2019, doi: 10.3390/en12020317.

[23] [23] M. Ramírez, R. Castellanos, G. Calderón, and O. Malik, "Placement and sizing of battery energy storage for primary frequency control in an isolated section of the Mexican power system," Electr. Power Syst. Res., vol. 160, pp. 142-150, Jul. 2018, doi: 10.1016/j.epsr.2018.02.013.

[24] [24] M. Fisher, J. Whitacre, and J. Apt, "A Simple Metric for Predicting Revenue from Electric Peak-Shaving and Optimal Battery
Sizing," Energy Technol., vol. 6, no. 4, pp. 649-657, Apr. 2018, doi: 10.1002/ente.201700549.

[25] [25] T. Bowen, I. Chernyakhovskiy, and P. Denholm, "Grid-Scale Battery Storage: Frequently Asked Questions." Accessed: Jan. 15, 2020. [Online]. Available: www.greeningthegrid.org.

[26] [26] IRENA, "Utility-Scale Batteries," 2019.

[27] [27] R. Hemmati, "Mobile model for distributed generations and battery energy storage systems in radial grids," J. Renew. Sustain. Energy, vol. 11, no. 2, Mar. 2019, doi: 10.1063/1.5079698.

[28] [28] J. Gonçalves, L. Neves, and A. G. Martins, "Multiobjective methodology for assessing the location of distributed electric energy storage," in Lecture Notes in Computer Science (including subseries Lecture Notes in Artificial Intelligence and Lecture Notes in Bioinformatics), 2015, vol. 9028, pp. 227-238, doi: 10.1007/978-3319-16549-3_19.

[29] [29] "Largest battery in Denmark to be installed on Bornholm - CEE." https://www.cee.elektro.dtu.dk/news/2019/03/largest-battery-indenmark-to-be-installed-on-bornholm?id=b1cafaa9-a836-4643-9f3f9113b47842c1 (accessed Nov. 16, 2020).

[30] [30] A. S. Tsagkou, E. D. K. D. I. Doukas, D. P. Labridis, A. G. Marinopoulos, and T. Tengner, "Stacking grid services with energy storage techno-economic analysis," 2017 IEEE Manchester PowerTech, Powertech 2017, 2017, doi: 10.1109/PTC.2017.7981004.

[31] [31] J. Østergaard and J. Nielsen, "The Bornholm Power System An Overview (Technical Report)," no. April, pp. 1-7, 2008, [Online]. Available:

http://ctt.sitecore.dtu.dk/upload/sites/powerlabdk/media/the_bornhol m_power_system_an_overview_v2.pdf.

[32] [32] M. Müller et al., "Evaluation of grid-level adaptability for stationary battery energy storage system applications in Europe," $J$. Energy Storage, vol. 9, pp. 1-11, 2017, doi: 10.1016/j.est.2016.11.005.

[33] [33] Asian Development Bank, Handbook on Battery Energy Storage System, no. December. 2018.

[34] [34] “Use Case 1 - Peak Shaving -." http://netfficient-project.eu/usecase-1/ (accessed Jul. 08, 2020).

[35] [35] "PowerLabDK." http://www.powerlab.dk/ (accessed Nov. 24, 2020).

[36] [36] "Bornholmernes eget energiselskab." https://www.beof.dk/ (accessed Nov. 24, 2020).

[37] [37] “Elnet Øst -.” https://elnetoest.dk/ (accessed Nov. 24, 2020).

[38] [38] “Home - NUVVE Corp." https://nuvve.com/ (accessed Nov. 24, 2020).

[39] [39] "Danfoss Engineering Tomorrow - explore energy efficient and innovative solutions for your industry | Danfoss." https://www.danfoss.com/en/ (accessed Nov. 24, 2020).

[40] [40] "Forside - European Energy - European Energy." https://europeanenergy.com/da/forside (accessed Nov. 24, 2020).

[41] [41] Acore, "Beyond Renewable Integration: The Energy Storage Value Proposition Beyond Renewable Integration: The Energy Storage Value Proposition AMERICAN COUNCIL ON RENEWABLE ENERGY," 2016, [Online]. Available: www.acore.org/programs/member-initiatives/power-generation.

[42] [42] A. Burlinson and M. Giulietti, "Non-traditional business models for city-scale energy storage: evidence from UK case studies," Econ. $e$ Polit. Ind., vol. 45, no. 2, pp. 215-242, 2018, doi: 10.1007/s40812-0170083-8.

[43] [43] "Supercharged: Challenges and opportunities in global battery storage markets Brochure / report title goes here / Section title goes here."

[44] [44] G. Fong, R. Moreira, and G. Strbac, "Economic analysis of energy storage business models," 2017 IEEE Manchester PowerTech, Powertech 2017, 2017, doi: 10.1109/PTC.2017.7980829. 